\title{
Mit Liv og Levned.
}

\author{
Af H. H. Steensvang.
}

III.

\section{Mine Børn.}

Aar efter Aar gik hen. Mine Børn var nu blevet til voksne og kunde hjælpe til i Bedriften, saa vi ikke. behøvede at holde saa mange Tjenestefolk. Vi sparede derved Løn, og jeg kunde mere sikkert opholde mig hjemme.

Imidlertid kom Budskabet om, at gamle Kong Frederik den Sjette var hensovet, og der blev anordnet almindelig Landesorg. Mig havde han været en haard Herre. De Sedler, jeg havde været med til at sætte i Omløb, var ikke synderlig ringere end Kongens egne, der ogsaa viste falsk Flag, men alligevel havde jeg faaet en haard Straf.

Da nu den nye Konge, Kristian den Ottende, var kommet paa Tronen, raadede mange af mine Venner mig til at indgaa til ham med Bøn om Benaad. ning. De mente, at jeg kunde benaades, da jeg ingen falske Sedler havde skrevet, men kun af Nød og Trang havde været med til at udbrede dem, og de mange Aar, jeg havde tilbragt som fredløs, syntes at være Straf nok. Folk, som rigtig forstod sig paa sligt, fik et saadant allerunderdanigst Bønskrift sat op og indsendt for mig.

Jævnsides dermed fik man min gamle Moder til at rejse til Augustenborg for at formaa den hertugelige Familie til at lægge sin Indflydelse $i$ Vægtskaalen for mig. Hun opnaaede imidlertid ikke andet, end at der forlangtes af hende, at hun skulde skaffe mig til Veje og ganske henfly til Kongens Naade, hvilket Forlangende hun besvarede med, at det var noget, hun ikke kunde.

Omtrent paa samme Maade gik det med Bønskriftet. Efter megen lang Tids Forløb ankom der allernaadigst Svar derpaa. Jeg havde allerunderdanigst at indstille mig, saa vilde man se, hvad der 
kunde gøres for mig. Men dette var nu det eneste, jeg ikke vilde. Hellere vilde jeg leve fredløs og forfulgt, men fri, i Mark og Skov, end paa ny indespærres i Fængsel i Aarevis eller maaske for Livstid.

Alt imens var mine Døtre blevet gift, den ældste med en Sømand, som købte en Gaard i Omegnen af Christiansfeld, den yngste med en Gaardmand $i$ vor egen By. Min Kone var derved igen anvist paa fremmed Hjælp, medens jeg havde stor Hjælp af min Søn, som ivrigt tog sig af Gaardens Drift.

I Stedet for Benaadning kom der nu noget ganske andet, thi et Aars Tid efter, at Svaret var kommet, begyndte den tredje store Forfølgelse.

Jeg havde en Dag lagt mig paa Sengen for at faa mig en lille Middagslur, da vi havde en varm Dag, og jeg havde arbejdet svært. Vor yngste Datter var lige kommet hjem for at besøge os og havde kun været inde nogle faa Minutter, da Hundene begyndte at give Hals. Med de Ord: "Det er ikke rigtigt!" sprang jeg ud af Sengen for at bringe mig i Sikkerhed, men det var allerede forsent, thi jeg hørte nu, at nogen kom hurtigt ind paa Forstuen. Der blev intet andet Skjulested for mig end et Hjørne bag Sengestedsdøren, hvor der hang nogle Klæder, blandt andet ogsaa en Kavaj. Jeg smuttede hurtigt om bag Døren og ind under Kavajen. Det var paa højeste Tid, thi $i$ det samme aabnedes Døren, og ind sprang tre Politibetjente. Men min Datter havde ogsaa anet Uraad og stod allerede i Stuen ved Siden af. Næppe hørte hun, at de kom ind, før hun løb gennem Huset, huggende voldsomt med Dørene som een, der er paa ilsom Flugt. Politiet troede, at det var mig, og de tre fo'r nu hurtigt bag efter hende, hele stuehuset igennem. Jeg greb min Kjole og et Par Støvler, sprang ud paa Forstuen og derfra gennem Loen og Stalden ud i det fri, hen til et Hegn, med hvilket jeg krøb et Stykke, og: da jeg mærkede, at der ingen var bag efter mig, fik jeg hurtigt Støvlerne paa og søgte noget længere bort fra Huset, hvor jeg skjult bag et levende Hegn standsede for at iagttage, hvad de vilde foretage sig, naar de kom ud af Huset. Det varede temmelig længe, inden de kom, og de gik saa uden videre ad Felsted til. Jeg listede mig tilbage, og nu fortalte man mig, hvorledes det var gaaet. De 
havde forfulgt min Datter saa længe, til de standsede $i$ en afsides Krog i Huset, saa at de ikke $i$ en Hast kunde finde tilbage til Dagligstuen. Da de kom tilbage til Dagligstuen, tog de Sengen og Krogen bag Døren i Øjesyn, og da de vel mærkede, at de var bleven overlistet, var de ikke saa synderligt milde stemte. De brugte Mund og havde villet forskrække min gamle Moder og min Datter, som imidlertid ikke var blevet Svar skyldig, hvorfor de ogsaa senere i Kroen i Felsted fortalte, at saavel den gamle som den unge havde forsvaret sig som et Par Advokater.

Den næste Nat opholdt jeg mig hos min Datter, og nogle Dage forløb i Ro, men en Eftermiddag hen imod Aften kom der igen tre Politibetjente, og de havde tre Pudelhunde med sig. Jeg var imidlertid blevet advaret og kunde sikre mig i Tide. Disse tre var stærkt berusede. De søgte i Huset, og de søgte i Marken, da de vidste, at jeg havde en Hule der. Deres Hunde fo'r omkring paa Marken, men mig fandt de ikke, og jeg var ikke bange, da jeg nok skulde holde mig Hundene fra. Kroppen, og tre berusede Politibetjente havde jeg ikke at frygte. Derfor sov jeg ogsaa roligt hjemme den næste Nat.

Det varede imidlertid ikke mange Dage, før de tre kom igen, og nu havde de faaet Forstærkning med sig, Troppen var blevet større. Denne Gang gik det ikke saa let at slippe, og jeg kunde ikke drive Gæk med dem som den sidste Gang, men de fik mig ikks, og jeg søgte Husly hos en Ven, hvor jeg blev den næste Nat og den følgende Dag. Det viste sig at være rigtigt, thi om Natten var de kommet igen.

$\mathrm{Nu}$ indsaa jeg, at jeg ikke kunde blive hjemme. Jeg tog Ophold hos Slægt og Venner og kom kun paa korte Besøg i mit Hjem. Næsten uafbrudt vedvarede Efterstræbelserne. Politiet syntes at have taget varigt Ophold paa Egnen. Derfor maatte jeg sige Farvel til min Hjemegn. Jeg opholdt mig et Par Dage hos Svogeren i Uge og vandrede saa videre nordpaa, hvor jeg foruden min Datter og Svigersøn havde flere Slægtninge og Bekendte. Jeg gik ikke den lige Vej, men søgte vestpaa, ud til de tyndt befolkede Egne. Forunderligt nok var mit Navn ogsaa kendt her. I en Kro hørte jeg saaledes nogle Gæster tale om mig. Der fortaltes, at der var kommet tre 
Politibetjente med tre Hunde, og at jeg havde drevet hele Selskabet paa Flugt, hvorefter jeg havde skrevet til Øvrigheden, at hvis de ikke havde andet at sende efter mig end tre drukne Politibetjente og tre Pudelhunde, saa maatte de hellere beholde dem hjemme. Desuden fortaltes der meget om min store Styrke, saa jeg kunde forstaa, at det var min Faders overordentlige Legemskræfter, man tillagde mig. Mest glædede det mig, at Folk ikke ansaa min Forseelse som særdeles stor.

Jeg levede nu deroppe en Tid, og saa kom der Bud fra Hjemmet, at Forfølgelserne syntes at være standset, hvorfor jeg hurtigt søgte hjem igen.

Maaske havde det en egen Grund, at Forfølgelserne ophørte. Medens jeg saaledes flakkede omkring, havde min Søn nemlig begivet sig til Kronprins Frederik, som til den Tid opholdt sig i Fredericia. Da Kronprinsen var kendt som en Mand, der havde et varmtfølende og deltagende Hjerte for Folks og især for den menige Mands Ve og Vel, thaabede min Søn ved hans Hjælp at udvirke min Frihed.

Min Søn opnaaede ogsaa straks at faa Avdiens, hos Kronprinsen, som venligt og deltagende hørte paa hans Fremstilling af Sagen og paa Fortællingen om de mange ulykkelige Aar, som jeg havde tilbragt under Forfølgelser og Lidelser. Min Søn fortalte ogsaa om Henvendelsen til Kongen og om det Svar, der var indløbet, og han sluttede med at bede Prinsen anvende sin Indflydelse for at redde saavel mig som min Familie ud af vor betræengte Stilling. Da Prinsen imidlertid hørte om Henvendelsen til Kongen og Svaret derpaa, sagde han straks: "Ja, saa kan jeg sagtens ikke udvirke din Faders Benaadning, saa ondt som det end gør mig for ham og thans Familie, thi jeg synes, at de mange Aar i Elendighed allerede er Straf nok. Og at han ikke saaledes vil overgive sig paa Naade og Unaade, fortænker jeg ham saamænd slet ikke i, det gjorde jeg heller ikke. Skal jeg imidlertid engang blive Konge, saa kom atter til mig, saa skal Din Fader faa sin Frihed, og alt, hvad jeg nu kan gøre for at hjælpe ham i hans betrængte Stilling, det vil jeg ikke undlade at gøre. Men«, henvendte Prinsen sig videre til min Søn, wer der da ikke noget, jeg kan gøre for Dig? Kom til mig, og jeg vil 
give Dig en Ansættelse, saa Du skal være vel forsørget Din hele Levetid! $\lll$

Min Søn bevidnede den gode og venlige Prins sin dybe Taknemmelighed, men sagde, at paa Grund af min ulykkelige Stilling kunde han ikke forlade sin Moder og gamle Bedstemoder, det var hans Pligt. at være dem til Hjælp og Bistand. "Det var smukt og sønligt tænkt«, sagdè Prinsen og gentog derpaa sit Løfte, at hvad godt han kunde gøre for mig, det vilde han gøre. Dermed var Avdiensen forbi. Min Søn opnaaede ikke, hvad han vilde, men jeg'havde al Grund til at være tilfreds. Forfølgelserne hørte nemlig pludselig op, og der var al Grund til at antage, at det var Prinsens Værk, idet han vist har givet. vedkommende Myndighed et Vink om, at han ønskede, man holdt inde med Forfølgelserne.

Jeg var i Fremtiden naturligvis aarvaagen, men tilbragte dog Tiden i mere Ro. Alt tegnede saaledes til det bedre, og vor pekuniære Stilling var ogsaa blevet betydelig bedre, saa at vi med Lethed kunde skaffe det nødvendige til Veje. Takket være min Søns dygtige og ihærdige Arbejde saa det saaledes ud til, at der skulde følge lysere Dage for min Kone og mig. Havde min Stilling ikke været saa ulykkelig, saa var min Søn vist kommet til Bogen ligesom min Broder, hvem han havde Navn efter. I Skoletiden udmærkede han sig saa stærkt, at Biskoppen eller Superintendenten, som det hed dengang, ved en Visitats tilligemed Provsten med al Magt vilde have ham til at studere. Der kunde nok blive en anden Peter Steensvang af ham, sagde de.

Men Skæbnen var endnu ikke træt af at forfølge mig. Thi nu begyndte min ellers kraftige og sunde Søn at blive svagelig. Det begyndte med en forfærdelig stærk Næseblødning. Det kunde jeg imidlertid nok hjælpe for, da jeg nok forstod at stille Blod ved hemmelige Midler. Men snart mærkedes det, at han led af en stærk tærende Sygdom, og al Lægehjælp kunde ikke hjælpe. Det varede ikke længe, før hans $\emptyset j n e$ lukkede sig for bestandigt. Enhver vil kunne forestille sig den Smerte, jeg maatte føle, og for min stakkels Kone, hans Moder, var det et frygteligt Slag. Tiden blev ogsaa for os den bedste Læge for dette Hjertesaar, saa at vi, om vi end tidt savnede vor gode 
Søn, dog nu mindedes ham med stille Vemod og Hengivenhed i Guds Vilje.

\section{Fri.}

Tiden gik uden nogen videre Forstyrrelse fra Politiets Side, saa at jeg selv kunde passe min Gaards Drift. Men nu begyndte Striden og Rivningerne mellem Dansk og Tysk, hvorved Befolkningen delte sig i to Partier.

Hos os var der kun faa, som sluttede sig til det tyske Parti, men der var dog nogle, som lod sig forsnakke af Embedsmænd og Godsejere. Trods alle Forfølgelser hang mit Hjerte ved Danmark. Jeg kunde heller ikke forstaa, hvad Gavn og Gunst vi Bønder kunde vente os af det tyske Godsejer- og Ridderskabsparti. Den Tid laa jo ikke saa langt tilbage, da disse Herrer havde kuet og plaget Bondestanden haardt nok. Eller hvad godt kunde vi i det. hele taget vente af Tyskerne? Jeg mindedes den gamle Digters Ord:

Før skal der vokse Figen paa Hylderod, før Tysken vorder den Danske god.

Forhandlingerne i Stændersalen fulgtes med spændt Opmærksomhed, og det glædede os hjerteligt, naar vi hørte, hvorledes vore Talsmænd havde forsvaret vort Sprog og vor Ret. De var imidlertid kun faa, da Valget til denne Stænderforsamling var saa. viseligt indrettet, at disse Herremænd og dette Ridderskab i Forening med en Del forræderske Embədsmænd og Præster kunde raade over de fleste Stemmer, omendskønt de kun var en Brøkdel af Landets Befolkning. Der spaaedes derfor nok af, at det vilde ende med Oprør og Krig, men det lod til, at baade Kongen og hans Regering sov saa fast, at de kun kunde vækkes af Kanonskud.

Mangt og meget viste tydeligt hen paa, at der var noget slemt $i$ Gære. Hertugen af Augustenborg foranstaltede Folkefester ved sit Slot paa Graasten, hvortil der blev stegt hele Okser paa Spid, medens Oprørssangen "Schleswig-Holstein" blev sunget for første Gang her paa Egnen. Folk forstod dog endnu. 
ikke rigtigt, hvilke Ulykker der pønsedes paa. Jeg erindrer endnu, at Folk bagefter fortalte og undrede sig over en Mand, som ved denne Fest gik og var saa vred, at han slog med sin Stok i Jorden. Det har været en af de faa, som tydeligt saa, hviad der var i Vente.

Der var ogsaa en anden Ting, som satte Folk i Forundring, nemlig Tyverier af Hestehaler. Naar Folks Heste om Sommeren gik paa Græs, blev Halerne skaaret af, og mærkeligt nok indtraf saadant blot ved dansksindede Folks Heste, ligesom det enkelte Steder opdagedes, at det ikke var simple Folk, men fint klædte Herrer, som forøvede disse Tyverier og Niddingestreger. De tysksindede benægtede det, men nogle af dem fik dog en Prøve af, hvad Folk mente om det, thi nu blev Halen ogsaa skaaret af deres Heste, og det til Gavns, saa at Halestumpen var saa rent klippet, som om den var barberet. Naturligvis var det gjort af Folk, som var forbitrede over, at de skulde slippe fri, og at de oven i Købet vilde benægte Kendsgerningerne.

Ogsaa mine Heste havde Besøg af Tyvene, men der var de kommet lige til Pas, thi det var saadanne Dyr, som vel var fromme og omgængelige mod de Folk, de var vant til, men derimod saa arrige mod fremmede, at de ikke var til at komme nær. Tyvene havde begyndt at skære i Halen paa den ene Hest, men saa maa den anden være kommet sin Kammerat til Hjælp og det for ramme Alvor. En stor Søle af størknet Blod viste Dagen efter, hvor uheldige Tyvene her havde været. Folk i Nabolaget havde ogsaa hørt Raaben og Skrigen om Hjælp. Naturligvis var der blevet raabt i det tyske Sprog.

Der ymtedes blandt Folk, at disse Hestehaler nok samledes sammen til Brug i en Arme, hvilket ogsaa senere viste sig at være rigtigt, thi Oprørerne havde Hestehaler paa deres Chakoer.

Da Kristian den Ottende hensov i Aaret 1848, og den nye Konge, Frederik den Syvende, havde besteget Tronen, brød det længe forberedte Oprør ogsaa løs. I vort Sogn vilde en Herremand og Præsten*) ved Løgn

*) Pastor Bertel Petersen Godt, f. i Rinkenæs 1814, Præst i Felsted 1846-51, i Hagen i Westfalen 1851-64, Generalsuperintendent i Slesvig 1864-1885. 
og Underfundighed overtale Folk til at gribe til Vaaben og slutte sig til Rebellerne, men de havde ikke Held dermed. De maatte tværtimod være glade ved, at de selv undgik den forbitrede Befolknings Hævn. Da Indkaldelsesordren kom til de hjempermitterede Soldater, søgte disse nordpaa til deres gamle Faner i Stedet for at drage sydpaa. De unge Karle derimod, som stod for at blive Soldater, søgte at redde sig ved at flygte til Als eller andre Øer, hvor Fjenden ikke kunde komme. Men enkelte blev dog tagne med Magt og ført til Rendsborg, hvor man stak dem ind i Oprørernes Rækker.

Det varede ikke ret længe, inden vi fik de oprørske Friskarer, bestaaende af Kieler Studenter og alle Slags sammenløbet Pak fra Tyskland, at se hos os, og nogle Landsbyer blev slemt udplyndrede. Men nu begyndte ogsaa vore egne Tropper at komme, og Friskarerne søgte atter mod Syd. De blev saa grundigt slaaet ved Bov, at vi haabede, nu var denne Krig forbi, hvad den vel ogsaa havde været, hvis de ikke havde faaet $H j æ l p$ af Prøjsen og det tyske Forbund. Glæden over Sejren ved Bov var derfor kun kort. 14 Dage derefter maatte vor Hær trække sig tilbage til Als, og Landet blev oversvømmet af de fremmede Tropper.

Under alle disse Begivenheder havde jeg søgt at gøre mig saa nyttig for den danske Sag, som jeg kunde. Jeg overbragte den danske General Efterretninger om Fjendens Stilling og Hensigter, saa vidt jeg kunde opdage det, og jeg gavnede paa anden Maade vor Sag, hvor jeg saa Udvej dertil. Af den Grund følte jeg mig heller ikke tryg, da Landet blev besat af de fremmede Tropper. Jeg opholdt mig derfor mest i Nærheden af vor egen Hær, hvor min Tjeneste ogsaa taknemmeligt blev modtaget af de danske Officerer.

Jeg var saaledes engang sammen med Generalerne Bülow og Schleppegrell og bragte dem nogle Efterretninger, som de ønskede at faa. Da jeg var færdig med min Beretning, saa General Bülow paa mig og sagde: "Jeg synes, Du ser bleg og angrebet ud, Du gaar dog ikke og lider Mangel her hos os?" Schleppegrell føjede til: "Ja, Mangel maa han ikke lide.« Bülow tog derpaa nogle Penge og vilde give 
mig dem, men jeg afslog at modtage dem med de Ord: "Jeg gør ikke denne Tjeneste for at tjene Penge." "Ja", sagde han, "det ved jeg nok. Men noget. skal du alligevel have. Vi Soldater faar dog det nødvendige til Livets Ophold, og det skal Du ogsaa have." Han trykkede mig derpaa 10 Specier (40 Kr.) i Haanden og bad mig komme igen, saa snart der var noget at melde om de fjendtlige Bevægelser.

Jeg kom ogsaa ud til vore Krigsskibe, og det var til dem, at min første nogenlunde frie Udflugt gik for sig. Straks efter Oprørets Udbrud kom der et Orlogsskib og lagde sig i Aabenraa Fjord, et lille Stykke fra Byen, for at tvinge den oprørske Øvrighed til Lydighed. Med flere andre sejlede jeg ud til Skibet for at tilbyde vor Tjeneste for den danske Sag, ved det private Efterretningsvæsen. Jeg lagde Mærke til, at Skibets Kanoner var rettede lige mod Kirken ogsagde dette til en Officer. Denne svarede: "Ja, først Kirken, og hvis denne Rakkerrede saa ikke falder til Føje, saa Raadhuset." Jeg gjorde opmærksom paa, at ræsten hele Borgerskabet dog var den danske Sag tro hengiven. Ja, det vidste han ogsaa godt, men nu var Byen i fremmed Paks Vold, og de skulde bringes. til at fortrække eller til at underkaste sig.

Jeg havde saaledes nok at bestille, idet jeg snart søgte ud paa Søen og snart var til Lands, og ganske uden personlig Fare var det heller ikke; gentagne Gange hørte jeg Kuglerne hvine omkring mig. I Kampene ved Dybbøl var jeg ogsaa til Stede, og der fik jeg Erfaring for, hvor lidt Folk forstaar sig paa Krigerhaandværket, naar de ikke er oplærte i det. Som jeg gik omkring for at være til Nytte, hvor jeg kunde, kom jeg ogsaa gennem en Lavning mellem to Bakker og traf her et Batteri i god Ro. Jeg kunde ikke dy mig for at sige: "Hvorfor holder I her i Skjul og udretter ingen Ting, medens den øvrige Hær kæmper saa tappert mod Fjenden?" Batteriets Kommandør smilede over min Iver og sagde: "Det forstaar De Dem ikke paa, min gode Mand. Ret nu skal De faa Batteriet at se i fuldt Arbejde." Kort efter gav han et kort Kommandoraab, og nu fo'r Batteriet $i$ voldsom Fart op paa Bakken, og med en mageløs Hurtighed begyndte det Skydningen. Men Gud bevare os vel, som Fjendens Lemmer nu hvirvledes i Vejret! Det var et grufuldt Syn. 
Jeg fulgte dette Batteri, da Fjenden trak sig tilbage i ilsom Flugt, gennem Dybbøl og Stenderup, h.vor det atter piskede Fjenden bort fra en Vejrmølle et Stykke Vest for Byen. Jeg begav mig derpaa til en Ven i Sottrup, og da jeg derfra bragte i Erfaring, at hele Egnen til hinsides Graasten var renset for Fjenden, begav jeg mig til mit Hjem.

Opholdet her blev ikke af lang Varighed. Snart havde vi igen Fjenden paa Egnen, hvorfor jeg atter maatte tage Afsked, dels for at bringe den danske Overkommando Tidende om noget, som jeg havde faaet Kundskab til, dels ogsaa, fordi det ikke var hyggeligt for mig hjemme, naar den tyske Indkvartering var paa Egnen. Baade til min Datter og til mine Tjenestefolk havde de ytret sig om, at jeg var en dansk Spion, hvilket var dem bibragt af Egnens Hjemmetyskere. At de havde denne Mening hidrørte fra en Sammenkomst, som jeg havde med nogle af vore Søofficerer hos en Mand paa Løjt Land, som gik for at være dansksindet, men hemmeligt holdt med Fjenden.'Han havde luret sig til at hore noget af vor Samtale og havde ogsaa hørt mig nævne med Navn, og hvad han saaledes havde luret sig til, havde han meddelt til andre igesindede.

Det var saaledes et ustadigt og omflakkende Liv, som jeg førte. Men allevegne, hvor jeg vankede omkring, fandt jeg Venner og ligesindede Hjælpere.

Ved alt dette kom jeg ogsaa flere Gange til at staa for vor Konge, xeg kunde herved ikke undlade at gøre Sammenligninger mellem den Modtagelse, jeg fik af ham, og den, jeg for mange Aar tilbage havde faaet af en anden Konge. Her var ingen Barskhed eller haard Tiltale. Mildt og venligt bod han mig træde nærmere og udspurgte mig nøje om forskellige Ting. Men mest laa det ham dog paa Sinde, hvorledes det gik hans kære Undersaatter her $\mathbf{i}$ Slesvig $\mathrm{i}$ denne ulykkelige Krigens Tid, at de dog ikke skulde lide for stor Overlast af de troløse oprorere.

Ved disse Foretræder for Kongen fik jeg ogsaa Lejlighed til at forebringe mine egne Anliggender for ham. Han udspurgte mig nu meget nøje, saa at jeg, der havde tænkt, at jeg skulde fatte mig i Korthed, nu maatte give en lang Fortælling om de forskellige 
Begivenheder under min Flugt fra Fængslet og de Forfølgelser, som var overgaaet mig, og noget af det lod næsten til at more ham. Han erindrede nu ogsaa godt, at min Søn havde været hos ham i Fredericia, og spurgte, hvorledes det gik ham, om han var hjemme, eller om han maaske nu ogsaa var Soldat. Da jeg fortalte, at han var død allerede for flere Aar siden, udbrød han: "Det var da sørgeligt, at dette unge Menneske skulde forlade denne Verden saa hurtigt!" "Men nu", vedblev han, "synes mig, at Du. har lidt og bødet nok for denne Forseelse, da du tilmed ikke har været Ophavsmand eller Anstifter af denne Seddelhistorie. Derfor skal Du fra i Dag af være fri for al videre Tiltale i denne Sag."

Af ganske Hjerte takkede jeg naturligvis den gode Konge for hans store Naade imod mig. "Ja", sagde han, "lad nu det være godt! Du har jo nu ogsaa vist Dig tro imod Din Konge og Dit Folk og sat Liv og Frihed i Vove for at tjene vor Sag. Derfor skal Din fuldstændige Frihed nu ogsaa være Din Belønning." Endnu engang gentagende min inderligste Taksigelse forlod jeg med rort Hjerte min naadige og gode Konge.

Virkeligt tilstilledes der mig kort derefter en Skrivelse med Hans Majestæts Navn og Segl under, lydende paa: At da jeg frifandtes for at have forfærdiget de falske Sedler, saa fritoges jeg ved Kongens Naade for al videre Tiltale i bemeldte Sag. Det var rigtignok med jublende Glæde, at jeg modtog min genvundne fuldstændige Frihed, saa at jeg, der havde været jaget som et vildt Dyr paa Marken, nu kunde gaa aabenlyst, hvor jeg vilde. Men havde jeg ikke glemt at takke min Konge for hans Naade, saa glemte jeg heller ikke at takke min Gud for hans underfulde Førelse.

\section{Efterretningstjenesten.}

Med endnu større Iver søgte jeg nu at tjene vor Konge og vor Sag og kom derved til at flakke meget omkring i disse Krigsaar, og mange underlige Ture havde jeg. Saaledes var jeg ogsaa virksom for at faa det Batteri nedskudt, som Tyskerne havde bygget 
paa Holdnæs for at spærre Indsejlingen til Flensborg Fjord.

Der var lige ankommet et af vore Orlogsskibe, som hed "Najaden«. Det vilde i Kast med det fjendtlige Batteri, da jeg kom ud til det, men da det manglede Proviant, vilde det sejle tilbage for først at skaffe sig samme. Men jeg tilbød saa at besørge det. Med fleres Hjælp lykkedes det mig hurtigt at faa et godt Læs Fødevarer samlet, hovedsageligt bestaaende af Flæsk, Kød og Arter. Men da Fjenden jævnligt patrouillerede langs med Strandbredden, var det vanskeligere at faa det ud til Skibet. Vi fik det dog derud samme Nat ved Hjælp af en Fisker i Egernsund ved Navn Petersen. Først sagde han rigtignok, at han ikke turde for Patrouillen, men da jeg fortalte, at den lige var passeret forbi, kom han hurtigt paa Benene og gjorde Baaden sejlklar, hvorpaa vi to sejlede ud til Korvetten. Næste Dags Morgen begyndte Krigsskibet ogsaa Angrebet paa det fjendtlige Batteri, og det varede heller ikke saa ret længe, inden Fjenden var fordrevet og hans Batteri jævnet med Jorden. Skibet sendte ogsaa sine Kugler til Egernsund og Fisknæs og fordrev Fjenden derfra. Desværre blev derved en Kone skudt, da hun sad og gav sit Barn Die.

I Slaget ved Kolding holdt jeg mig mest til 12 . Bataillon, som jo bestod af vore egne Folk fra Nordslesvig. Her fik jeg ogsaa et Hverv at udføre. En højere Officer, som kendte mig personligt, bad mig om at opsøge nogle Proviantvogne og give Befalingsmændene Ordre til at trække sig længere tilbage, for at de ikke skulde falde i Fjendernes Hænder. En Underofficer ved disse Vogne svarede imidlertid, at han ikke tog mod nogen Ordre af Bønder. Følgen blev, at han blev taget til Fange af Tyskerne.

I nogen Tid blev jeg i Egnen ved Kolding. Derefter kom jeg til Fredericia og blev derfra sat over til Fyn. Det var med underlige Følelser, at jeg betragtede det Vand, som havde været Vidne til min farefulde Overfart for saa mange Aar tilbage, da jeg ene og alene ved Guds naadige Bistand undgik Døden i det frygteligt oprørte Hav. Det var med taknemmelige Følelser, at jeg nu som fri Mand gik omkring paa Fyn, hvor jeg engang som ulykkelig forfulgt 
Flygtning havde maattet døje Nød, Savn og Elendighed. Jeg gjorde ogsaa en Afstikker til Odense, og det var underligt at følge de samme Gader, som jeg hin Flugtnat saa ilsomt var løbet igennem. Jeg betragtede Raadhuset og Nabohusene og maatte betragte det som et Mirakel, at mit Spring fra Tag til Tag var lykkedes. Jeg søgte ogsaa at faa Kundskab om, hvorledes det var gaaet de andre Rigsbankfanger og kom derfor atter igennem Sognet V....... Saa vidt jeg kunde bringe i Erfaring, var de alle sammen ved Døden befriede for deres Lidelser.

Længe opholdt jeg mig dog ikke paa Fyn, hvor jeg ikke kunde gavne vor Sag. Jeg søgte atter tilbage til Sønderjylland, hvor jeg nu stadig var paa Færde. Mest havde jeg mit. Tilhold paa Als, og herfra gjorde jeg Udflugter til alle Sider af det slesvigske Fastland. Mange af disse Ture blev farlige rok, og gentagne Gange hørte jeg Kuglerne pibe mig om Ørerne, naar jeg satte af fra Landet, enten ud til vore Skibe eller til Als. Men ved mit lange fredløse Levned var jeg blevet vant til at være aarvaagen og forsigtig, og derfor slap jeg ogsaa altid heldigt fra de fjendtlige Efterstræbelser.

Budskabet om den store Sejr ved Fredericia løb om i Landet og modtoges med jublende Glæde. Men en Sorg var der dog ved denne Sejr, at den brave General Rye maatte lade sit Liv. Trods Glæden over Sejren var det en knugende Sorg for mig, at jeg ikke oftere skulde skue hans Ansigt eller høre venlige og opmuntrende Ord af hans Mund. Følgen af Slaget blev imidlertid, at Oprørerne Hals over Hoved maatte retirere sydpaa, og da der saaledes var mere Ro, blev jeg hjemme igen.

De faa tysksindede, der boede blandt os, vilde dog gerne endnu spille Mester og støtte sig paa Oprørsregeringens Anordninger. Derfor havde jeg mangen en hidsig Disput med dem. Følgen blev, at de angav mig som dansk Spion og udvirkede, at der blev sendt en Trop Rebeller ud for at fange mig.

Da der var Tale om Fredsforhandlinger og Vaabenstilstand, havde jeg naturligvis ingen Anelse om nogen Fare, tilmed, da fjendtlige Tropper nu ikke var os saa nær. Jeg blev derfor fuldstændig overrasket, da den omtalte Trop ankom, og overfor de 
mange velbevæbnede Modstandere maatte jeg overgive mig. Dette var imidlertid ikke nok for disse drabelige Helte, som var saa mange imod en enkelt ubevæbnet Mand. Nej! for at være fuldstændig uskadelig for dem, maatte jeg lænkes. Efter saa mange Aars Forløb fik jeg atter Læn்kerne at føle. Lænket paa Haand og Fod sad jeg nu udenfor min Dør paa en af de besynderlige, runde Sten, som jeg havde liggende der, og drak den Kaffe, som min Kone grædende bragte ud til mig. Efter at jeg havde taget Afsked fra min Kone og mine Folk, som yderst forbitrede stod og saa paa den Behandling, som blev mig til Del, hjalp man mig op paa. en Vogn, som de havde bragt med. Og nu gik Rejsen for sig til Tønder, som endnu var besat af fjendtligt Militær.

Mine Bevogtere sang og jublede, især i Førstningen, over deres heldige Fangt. Nogle af dem beEyndte ogsaa at tale om, at jeg vilde blive hængt eller skudt. Ellers kan jeg ikke sige, at jeg blev saa ilde behandlet af dem, og paa Vejen blev jeg betragtet med medlidende Blikke af de Beboere, som erfarede, hvorfor jeg var arresteret, lige som jeg ogsaa kunde se Harmen i manges Aasyn, fordi jeg var i Lænker paa Grund af Troskab mod Konge og Fædreland. Blot i Tønder, hvor der er mange tysksindede, kunde jeg høre Haan mod mig og Glæde over, at en dansk Spion var taget til Fange.

I Tønder blev jeg indsat i Arresten, og Lænkerne blev taget af mig, efter at jeg var blevet forsvarligt indlaaset. Behandlingen og Forplejningen var ikke daarlig, men Friheden, som jeg havde vovet og lidt saa meget for, var mig dog berøvet. Gentagne Gange blev jeg ført i Forhør, og de sagde, at de havde paalidelige Beviser for mit Spioneri, som de kaldte det. $\mathrm{Nu}$ kom det for en Dag, hvorledes vi var blevne belurede ved den før omtalte Sammenkomst med Steen Bille paa Løjt Land, hvorledes der havde været Tyskere skjult i Huset, som havde hørt vor Samtale. Beskyldningen for at være en Spion afviste jeg. Vel havde jeg søgt at gøre Tjeneste for min Konge og mit Land, men dette ansaa jeg ikke for Spioneri og Forbrydelse, men for noget, som var enhver retskaffen Mands Pligt og Skyldighed.

I det hele fik jeg snart. Indtrykket af, at de vist- 
nok havde været glade ved, ikke at faa mig at trækkes med under de Omstændigheder, som nu herskede i Landet. Thi der var sluttet Fred med Preussen og Forbundet, og en Kommission var udnævnt til at styre Landet i vor Konges Navn. Følgeligt kunde de ikke saa godt benævne hans tro Mænd for Spioner og Landsforrædere, og denne tyske Øvrighed vidste selv næppe, hvad den skulde stille op med mig.

Uger efter Uger forløb imidlertid, og jeg blev siddende i Arresten, hvorfor jeg ogsaa saa smaat begyndte at lægge Flugtplaner. Jeg naaede dog ikke til at udføre et lignende Vovestykke som i Odense. Jeg fik nemlig Besøg af min Datter og min Svigersøn fra min Fødeby, som var kørte den lange Vej til Tønder for om muligt at bevirke min Befrielse. De: havde faaet Anvisning paa nogle Mænd i Tønder, som nok skulde hjælpe dem til Rette. De søgte ogsaa til en af disse Mænd, og han gik med dem til de forskellige Myndigheder. Enden blev, at jeg maaske nok kunde blive fri, naar min Svigersøn vilde gaa i Borgen for mig. Dette erklærede han sig villig til, der blev skrevet en Slags Protokol, som han underskrev, hvorpaa vedkommende Øvrighedsperson sagde til dem, at nu kunde de rejse roligt hjem, det vilde ikke vare længe, inden jeg blev losladt. Glade tog de derfor Afsked med mig og rejste hjem igen.

Der forløb imidlertid endnu otte Dages Tid, uden at der viste sig noget Tegn paa, at jeg skulde slippe løs. Men endelig blev jeg en skøn Dag hentet ud af Fængslet og ført til vedkommende Myndighed. Man læste for mig, at jeg paa Grund af min Svigersøns Kavtion blev frigivet, at jeg nu kunde begive mig til mit Hjem, hvor jeg i Fremtiden havde at forholde mig rolig, da jeg i modsat Tilfælde skulde hjemfalde til Lovens strengeste Straf, hvilket jeg altsammen ansaa for noget Vrøvl og Vaas, da jeg vidste, at de paa Grund af de politiske Begivenheder hverken kunde eller turde beholde mig længere i Fangenskab.

Hele det derpaa følgende Efteraar og den følgende Vinter tilbragte jeg i Ro i Hjemmet. Men da der i Foraaret og først paa Sommeren gik Rygter om, at Krigen skulde begynde igen, fordi Oprorerne. 
forstærkede deres Hær ved Tilgang af Folk fra Tyskland, besluttede jeg mig til at foretage en Udflugt sydpaa for at se, hvorledes Sagerne stod. Jeg kom helt ned til Egnen ved Rendsborg og behøvede ikke at opholde mig længe der, da jeg hurtigt nok erfarede, hvad der var i Gære. Oprørernes Tropper marcherede nordpaa og forkyndte højlydt, at nu skulde Dansken fuldstændigt jages ud af Slesvig. Hurtigt gik jeg derfor tilbage igen og tog Vejen op gennem Angel, hvor der var mange, som var den danske Sag tro og hengiven. Derfra lod jeg mig sætte over til Als og aflagde Melding om, hvad jeg havde set.

Saa kom det store og blodige Slag ved Isted. Glæden blev blandet med Sorg over de mange tapre Mænd, som her maatte lade Livet for Kongens og Fædrelandets Ret. Især gik den brave Schleppegrels Fald mig til Hjertet. Ham, som jeg saa ofte havde været sammen med, og som var saa varmtfølende for os Danske, ham skulde jeg nu ikke oftere tale med.

\section{Livsaften.}

Omsider blev der Fred og Ro i Landet, og jeg havde ogsaa faaet Fred og Frihed. Men saa forunderligt som det maaske end vil lyde for manges Øren, fandt jeg, der havde tilbragt saa mange Aar i Spænding og stadig Uro, denne gode Ro næsten trættende. Det var mig, som om jeg savnede den Spænding, som hint urolige Liv førte med sig. For at have noget at sysle med for Tankerne, fulgte jeg med Opmærksomhed vor Regerings Kævlerier med det tyske Forbund og med Tyskerne $i$ vort eget Land. Det behagede mig slet ikke, da jeg syntes, at det stilede mod en ny Krig.

Et Aars Tid efter, at vi havde faaet Fred og Ro i Landet, døde min gamle Moder i en høj Alderdom*), og da min Kone nu ogsaa begyndte at blive svagelig,

*) Pastor Mørk-Hansen skriver i Kirkebogen: "Ved Oprøret $1848 \mathrm{og}$ Sønnens Bortførelse af Tyskerne mistede hun Hørelse og Sjælskræfter, saa at hun siden kun var en Skygge af, hvad hun havde været." - Hun havde været Enke i 51 Aar og Aftægtskone i 36 Aar. 
besluttede jeg at sælge det Hjem, som jeg til sin Tid havde kæmpet saa haardnakket for at beholde. Jeg kunde gøre det uden Skrupler, da den rette Arving, min Søn, for lang Tid siden var indgaaet til et bedre Liv, og da ingen af mine Svigersønner viste Lyst til at overtage Gaarden. Det lykkedes ogsaa snart at faa min Gaard solgt, og jeg flyttede til Sønderborg, hvor jeg boede et Aars Tid. Herfra gjorde jeg bl. a. et Par Rejser til København til Ministeren for de slesvigske Anliggender angaaende politiske Sager.

Jeg blev imidlertid snart ked af dette orkesløse Liv, og min Kone kunde slet ikke finde-sig i dette Byliv. Derfor købte jeg meget billigt et lille Landsted, beliggende lidt sydfor Christiansfeld.") Da den gamle Kongevej førte lige forbi vor Dør og den nys anlagte Chausse heller ikke var langt derfra, boede vi smukt og vel tilfreds i den smukke, frugtbare Egn. Ofte gjorde jeg en Tur til Haderslev, hvor jeg havde Omgang med P. Koch, Redaktøren af "Dannevirke" og andre kendte Mænd. Tiden forløb saaledes godt for mig, men nu blev min Kone stedse svagere. Vi begyndte begge at ældes, men for hende slog der ogsaa en anden Sygdom til. Da min Svigersøn og Datter i min Fødeby havde et tomt Beboelseshus staaende, forlangte de, at vi skulde drage til dem, for at min Kone kunde faa en bedre Pleje.

Jeg solgte saa min lille Ejendom, og nu flyttede vi tilbage til vor Fødeby. Der forløb imidlertid kun et Par Aar, saa lukkede min trofaste Livsledsagerinde sine Øjne for stedse. Vi havde med hinanden gennemlevet et Liv fuldt af Modgang og Genvordigheder, men vi havde delt baade onde og gode Dage med hinanden i gensidig Kærlighed. $\mathrm{Nu}$, da hun endelig havde fundet en Rolighedshavn, hvortil hun kunde trænge saa haardt, bortkaldtes hun, og jeg lodes tilbage med mit dybe Savn. *)

Alt som Tiden gik, lindredes ogsaa denne Smerte, og mit Liv hengled nu i uvant Rolighed. Jeg læste meget $i$ mine Bøger og foretog ogsaa smaa Udflug-

*) I Bjerning.

*) I Kirkebogen skriver Pastor Mørk-Hansen om hende: "Hun har med denne sin Mand gennemgaaet meget, - - - men hun var altid taalmodig." 
ter til de omliggende Købstæder. Jeg hjalp ogsaa Frederik Fischer i Aabenraa med at samle de slesvigske Folkesagn. Men en Ting huede mig ikke, og det var de evindelige Bryderier, som vor Regering havde med Tyskerne. Efter alle Varsler at dømme vilde vi faa en ny Krig med disse rovbegærlige Fjender.

Allerede længe: var jeg af Venner og Bekendte blevet opfordret til at opskrive og udgive mine Livserindringer. Jeg fik derfor nok at bestille med at eftertænke mit sorg- og kummerfulde bevægede og urolige Liv. Der var allerede meget Arbejde ved de forberedende Optegnelser, og blot det vigtigste vil jeg fortælle, ellers kunde jeg fylde hele Bind.

\section{Slutning.}

(Skrevet af Steensvangs Dattersøn Jørgen Jørgensen Andersen).

Han naaede ikke at faa denne Levnedsbeskrivelse fuldført, da en brat og uventet Død bortrev den endnu saa kraftige Mand,") et Aars Tid før Krigen i 1864, som han saa ofte havde forudsagt og frygtet. Denne Krigs ulykkelige Udfald og sørgelige Følger kom han saaledes ikke til at opleve. Vel var det maaske, da han vistnok vanskeligt vilde have fundet sig tilfreds under de nye Forhold.

Men lige til det sidste bevarede han sit frejdige Sind og stolede trygt paa Guds Godhed og Naade, følende varmt for alt, hvad der var Ret og hadende al Uretfærdighed, hvorfor ogsaa en Ven af ham, som kendte hans frejdige og gudhengivne Sind, i et Digt, som han lagde paa hans Baare, udtalte følgende:

Saare stormfuldt var. mit Liv her nede, Voldsomt Bølgerne omkring mig slog.

Men til Kamp mod Modgang var jeg rede, Og med frejdigt Mod min Vej jeg drog.

$\mathrm{Nu}$ for mig er. Livets Kamp forsvunden, Jeg i Himlen sikker Havn har funden.

*) I Følge Felsted Kirkebog døde han efter kort Tids Sygdom af en Brokskade. 